\title{
Bone-Seeking Targeted Radio-Nuclide Therapy (BT-RNT) in Management of Metastatic Castration-Resistant Prostate Cancer (mCRPC): Shifting from Palliation to Improving Survival
}

\author{
Vimoj J Nair ${ }^{1}$, Colin Malone ${ }^{2}$, Patricia Moretto ${ }^{3}$, Eugene Leung ${ }^{3}$ and Shawn Malone ${ }^{1 *}$ \\ ${ }^{1}$ Division of Radiation Oncology, University of Ottawa and Ottawa Hospital, Ottawa, Canada \\ ${ }^{2}$ Division of Medical Oncology, University of Ottawa and Ottawa Hospital, Ottawa, Canada \\ ${ }^{3}$ Division of Nuclear Medicine, University of Ottawa and Ottawa Hospital, Ottawa, Canada
}

*Corresponding author: Shawn Malone, Associate Professor, Department of Radiation Oncology, The Ottawa Hospital Cancer Centre, 501 Smyth Road, Ottawa, Ontario, K1H 8L6, Canada, Tel: 001-613-737-7700; E-mail: smalone@ottawahospital.on.ca

Received date: Oct 16, 2014, Accepted date: Nov 28, 2014, Publication date: Dec 01, 2014

Copyright: (c) 2014 Nair VJ, et al. This is an open-access article distributed under the terms of the Creative Commons Attribution License, which permits unrestricted use, distribution, and reproduction in any medium, provided the original author and source are credited.

\begin{abstract}
Background: The purpose of this article is to review the role of bone-seeking targeted radionuclide therapy (BTRNT) in metastatic prostate cancer. The mechanisms of actions, radiobiology and clinical benefits of BT-RNTs will be reviewed.

Methods: Relevant studies of CRPC and targeted therapies were identified from literature and clinical trial databases, websites, and conference abstracts.

Results: BT-RNT in mCRPC has a proven beneficial palliative role in treatment of patients with mCRPC. The use of these agents as a monotherapy as well as combination with other palliative therapies are evolving. Among the various BT-RNT's the alpha emitter ${ }^{223} \mathrm{Ra}$ which is highly targeted and well tolerated has shown significant clinical benefit and survival advantage in this patient population.
\end{abstract}

Conclusion: BT-RNT represents an exciting treatment option for patients with mCRPC. ${ }^{223}$ Ra represents a new treatment paradigm for patients with $\mathrm{mCRPC}$.

Keywords: mCRPC; BT-RNT; Alpharidin; Radium-223; Radiotherapy; Prostate cancer

\section{Introduction}

Despite the success of various hormonal and local therapies, a significant percentage of patients with prostate cancer will recur and develop metastatic disease. Standard therapy for metastatic prostate cancer is Androgen Deprivation Therapy achieved by orchiectomy or medical castration. Inevitably patients with metastatic prostate cancer develop castrate resistant disease. Approximately $90 \%$ of patients with castration-resistant prostate cancer (CRPC) develop bone metastases. Despite the advent of novel therapies, the prognosis of castrationresistant prostate cancer (CRPC) remains poor with a median survival of approximately 24 months [1,2].

Bone metastases are a significant source of morbidity and mortality in prostate cancer [1]. When patients develop bone metastases, treatment strategies are used to palliate symptoms, reduces skeletal complications and extends survival. Palliative and survival benefits of therapy in this patient population must be weighed against toxicities of therapy. Recent agents such as carbazitaxel, Abiraterone and Enzalutamide show moderate improved survival in mCRPC; however, there is a need for interventions to further increase survival, palliate symptoms and improve quality of life in this setting [2].

Bone targeted therapies include anti-resorptive agents, boneseeking targeted radionuclide therapy and external beam radiotherapy.
Anti-resorptive agents (e.g.: zolendronic acid, denosumab) inhibit osteoclast activity and help to delay Skeletal Related Events (SREs); however, these agents have no impact on survival. Bone-seeking targeted radionuclide therapy (BT-RNT) using radiopharmaceuticals have been used for decades in MCRPC as a palliative therapy. External beam radiotherapy is routinely used to palliate painful bone metastases with high response rates.

\section{Bone-seeking Targeted Radionuclide Therapy (BT- RNT) and Bone Metastases}

Owing to the large bone tumor burden in patients with metastatic CRPC (mCRPC), there is significant interest in agents that could broadly target and eradicate prostate cancer cells in the bone. BT-RNT systemically seeks out active sites of bone metastasis and delivers tumoricidal radiation focally at the site where cancer interacts with bone. The benefit of this technique, compared to external beam radiation therapy, is that multiple sites of metastatic disease can be treated simultaneously. BT-RNT can also treat asymptomatic tumour sites in the bone which may help to reduce future complications and SRE's. In addition due to the localized targeting of cancer, there is in theory minimal radiation exposure to nearby tissues with relative sparing of normal bone, bone marrow and adjacent tissues.

Active prostate cancer cells within the bone metastasis alters the skeletal metabolic activity around it, resulting in an active bone synthesis process characterised by local increase in the uptake of 
Citation: Nair VJ, Malone C, Moretto P, Leung E, Malone S (2014) Bone-Seeking Targeted Radio-Nuclide Therapy (BT-RNT) in Management of Metastatic Castration-Resistant Prostate Cancer (mCRPC): Shifting from Palliation to Improving Survival. J Nucl Med Radiat Ther 6: 202. doi:10.4172/2155-9619.1000202

Page 2 of 8

calcium, which is used to construct hydroxyapatite. It is believed that the cancer cells secrete pro-osteoblastic factors that promote bone mineralization. In addition, the cancer cells also produce proosteoclastic factors such as receptor activator of NFkappaB ligand (RANKL). Thus the inhibition of the prostate cancer cells using radiation would help in inhibiting both the osteoblastic and osteoclastic effects of bone metastasis. This in-turn should palliate pain and reduced risk of SREs. In addition tumoricidal effects of radionuclide therapy could lessen tumor burden and potentially improve survival [3].

BT-RNT for palliation of pain from bone metastases has been used successfully for decades [4]. In 1941, a patient with prostate cancer and

\begin{tabular}{|c|c|c|c|c|c|c|c|c|c|}
\hline Radiopharmaceutical & $\begin{array}{l}\text { Half-life } \\
\text { (t } 1 / 2)\end{array}$ & $\begin{array}{l}\text { Maximum } \\
\text { beta }(\beta) \\
\text { nergy in MeV } \\
\text { (mean) }\end{array}$ & $\begin{array}{l}\text { Mean } \\
\text { alpha }(\alpha) \\
\text { energy } \\
\text { in MeV }\end{array}$ & $\begin{array}{l}\text { Mean } \\
\text { gamma } \\
\text { (v) } \\
\text { energy } \\
\text { in keV }\end{array}$ & $\begin{array}{l}\text { Maximum } \\
\text { tissue } \\
\text { penetration } \\
\text { (mean) }\end{array}$ & $\begin{array}{l}\text { Usual } \\
\text { administered } \\
\text { activity } \\
\text { units) }\end{array}$ & $\begin{array}{l}\text { Typical } \\
\text { response } \\
\text { time }\end{array}$ & $\begin{array}{l}\text { Typical } \\
\text { response } \\
\text { duration }\end{array}$ & $\begin{array}{l}\text { Retreatment } \\
\text { interval }\end{array}$ \\
\hline Phosphorus $\left[{ }^{32} \mathrm{P}\right]$ & 14.3 & 1.71 & _ & None & $8 \mathrm{~mm}(3 \mathrm{~mm})$ & $\begin{array}{l}5-10 \quad \mathrm{mCi} \\
(185-370 \mathrm{MBq})\end{array}$ & & & \\
\hline $\begin{array}{l}\text { Strontium-89 }\left[{ }^{89} \mathrm{SrCl} 2\right] \\
\text { (Metastron } ®\end{array}$ & $\begin{array}{l}50.5 \text { days } \\
(14 \text { days } \\
\text { biological } \\
\mathrm{T} 1 / 2)\end{array}$ & $1.46(0.58)$ & - & none & $\begin{array}{l}5.5 \mathrm{~mm} \quad(2.4 \\
\mathrm{mm})\end{array}$ & $\begin{array}{l}4 \mathrm{mCi} / \mathrm{kg} \quad(1.48 \\
\mathrm{MBq} / \mathrm{kg})\end{array}$ & $14-28$ days & $12-26$ weeks & $>3$ months \\
\hline $\begin{array}{l}\text { Samarium-153 [153Sm- } \\
\left.\text { EDTMP] (Quadramet }{ }^{\circledR}\right)\end{array}$ & 1.9 days & $0.81(0.22)$ & - & 103 & $\begin{array}{l}2.5 \mathrm{~mm} \quad(0.6 \\
\mathrm{mm}\end{array}$ & $\begin{array}{l}1 \mathrm{mCi} / \mathrm{kg} \quad 37 \\
\mathrm{MBq} / \mathrm{kg})\end{array}$ & 2-7 days & 8 weeks & $>2$ months \\
\hline $\begin{array}{l}\text { Radium-223 }\left[{ }^{223} \mathrm{RaCl} 2\right] \\
\text { (Alpharadin } ® \text { ) }\end{array}$ & 11.4 days & - & 5.64 & - & $<0.1 \mathrm{~mm}$ & $\begin{array}{l}1.35 \mathrm{kCi} / \mathrm{kg} \quad(50 \\
\mathrm{kBq} / \mathrm{kg})\end{array}$ & $<10$ days & $\begin{array}{l}\text { Not } \\
\text { established }\end{array}$ & Not established \\
\hline Stannic-117 & $\begin{array}{ll}\begin{array}{ll}13 . \\
\text { days }\end{array} & 6\end{array}$ & $\begin{array}{l}\text { (conversion } \\
\text { electron) }\end{array}$ & - & 159 & $0.2-0.3 \mathrm{~mm}$ & $\sim 333 \mathrm{MBq}$ & $5-19$ days & 98 days & Not established \\
\hline Rhenium-186 [ ${ }^{186}$ Re-HEDP $\}$ & 3.8 days & $1.07(0.35)$ & - & 137 & $\begin{array}{l}4.5 \mathrm{~mm} \quad(1.1 \\
\mathrm{mm})\end{array}$ & $\begin{array}{l}35 \mathrm{mCi} \quad(1295 \\
\mathrm{MBq})\end{array}$ & 2-7 days & 8-10 weeks & $>2$ months \\
\hline
\end{tabular}

Table 1: Physical characteristics of Bone seeking radiopharmaceuticals.

\section{Mechanism of Action of BT-RNT}

Bone metastases in prostate cancer are predominantly osteoblastic. The bone targeting of most radiopharmaceuticals in prostate cancer relies on selective uptake and prolonged retention of the isotopes (or their chelated complexes) at sites of increased osteoblastic activity. This enables delivery of ionizing radiation to areas of amplified osteoblastic activity in multiple sites simultaneously. The radiopharmaceuticals target both symptomatic and asymptomatic sites [7] (Figure 1). It is unclear whether the BT-RNT produces response through disruption of an onconiche (where osteoblasts provides a microenvironment which supports and sustains cancer stem cells) or due to eradication of micrometastatic disease [8].

Bone targeting agents like ${ }^{89} \mathrm{Sr}$ and ${ }^{223} \mathrm{Ra}$ are calcium mimetic, as they are members of the second group of periodic table. Similar to calcium, they are incorporated into hydroxyapatite at the sites of high osteoblastic activity. Radioisotopes such as samarium $\left({ }^{153} \mathrm{Sm}\right)$ and rhenium $\left({ }^{186} \mathrm{Re},{ }^{188} \mathrm{Re}\right)$ require complexing with a chelate such as ethylenediamine tetramethylene phosphonic acid (EDTMP) or hydroxyethylidene diphosphonate (HEDP) to achieve selective uptake to the bone. After injection, these "isotope-carrier complexes" attach to the hydroxyapatite in mineralized bone, particularly in areas of high bone turnover at metastatic sites. painful osteoblastic bone metastases was treated with $8 \mathrm{mCi}$ of $\mathrm{Sr}-89$ with positive pain response, which was the first clinical use of radionuclide therapy for bone metastases [5]. Radioactive phosphorus $\left.{ }^{(22} \mathrm{P}\right)$ and ${ }^{89} \mathrm{Sr}$ were the first bone-seeking radiopharmaceuticals to be approved for treatment of bone metastases. However the use of ${ }^{32} \mathrm{P}$ waned due to the high rates of myelotoxicity [6]. The most popular BT-RNT agents currently in clinical use in mCRPC are the radionuclides ${ }^{89} \mathrm{Sr},{ }^{153} \mathrm{Sm},{ }^{186} \mathrm{Re},{ }^{188} \mathrm{Re}$, and ${ }^{223} \mathrm{Ra}$. The physical characteristics of these agents are tabulated in Table 1. 
Citation: Nair VJ, Malone C, Moretto P, Leung E, Malone S (2014) Bone-Seeking Targeted Radio-Nuclide Therapy (BT-RNT) in Management of Metastatic Castration-Resistant Prostate Cancer (mCRPC): Shifting from Palliation to Improving Survival. J Nucl Med Radiat Ther 6: 202. doi:10.4172/2155-9619.1000202

Page 3 of 8

damage and cellular apoptosis. Additional properties of radionuclide therapy are the "bystander effect," in which cell signalling mechanisms (connexion 43 gap junctions) cause death of tumor cells adjoining the target cells [7] (Figure 1), and the "cross-fire effect" in which cells not directly targeted are killed by convergence of particle emissions from surrounding sites.

\section{Dosimetry and Radiobiological Considerations}

The dosimetry of BT-RNT is complex. The radiobiology developed for external beam radiation therapy does not apply to BT-RNT. In EBRT, there is a constant delivery of radiation dose in a short time period producing single or double strand DNA breaks in tumour cells. On the other hand, BT-RNT particle radiation is delivered in a nonuniform distribution, and continuously in decreasing amounts over a longer time period. Radiation delivery in BT-RNT depends on the physical radionuclide half-life and residence time of the administered radiopharmaceutical. Where EBRT is delivered in fractions to improve its effect, some authors consider BT-RNT to be a form of continuous fractionation.

Mechanisms of cell death by BT-RNT include effects of radiation on the cell surface through the ceramide pathway triggering cellular apoptosis. In addition, BT-RNT results in significant DNA damage with resultant cell necrosis and a secondary immunological response [9].

The actual radiation dose received by the target depends on factors such as the physical half-life, type of emission and its attendant energy and tissue penetration, biological transit time and clearance (Table 1). Depth of penetration is a significant clinical factor as different tumors extend over varying lengths. $\beta$-emitters such as ${ }^{153} \mathrm{Sm},{ }^{89} \mathrm{Sr}$, and ${ }^{186 / 188}$ Re have energies high enough to penetrate the tumor but low enough to help minimize dose to the bone marrow (an important dose limiting organ in BT-RNT). $\gamma$ rays penetrate deeper but are low dose and are used for post therapy imaging. The newer agent ${ }^{223} \mathrm{Ra}$ predominantly emits $\alpha$ rays which have a very short range (2 to 10 cell diameters). As a result the dose to surrounding normal bone marrow is minimized.

\begin{tabular}{|c|c|c|c|c|c|}
\hline & Trial & Methods & $\begin{array}{l}\text { No. of } \\
\text { patients }\end{array}$ & Technique & Outcomes \\
\hline \multirow{2}{*}{$\begin{array}{l}{ }^{89} \mathrm{Sr} \text { compared } \\
\text { to placebo }\end{array}$} & $\begin{array}{l}\text { Lewington et al. } \\
\text { (Phase III cross } \\
\text { over) [4]. }\end{array}$ & ${ }^{89} \mathrm{Sr}$ vs. placebo & 32 & $\begin{array}{l}150 \mathrm{MBq} \text { week } 1 \text { and } \\
150 \mathrm{MBq} \text { in week } 6 \text { if } \\
\text { needed }\end{array}$ & Pain reduction for ${ }^{89} \mathrm{Sr}$ arm $(p<0.01)$ \\
\hline & $\begin{array}{l}\text { Buchali et al. } \\
\text { (Phase I/II) [15]. }\end{array}$ & ${ }^{89} \mathrm{Sr}$ vs. placebo & 49 & $\begin{array}{l}75 \mathrm{MBq} \text { qmonths } \times 3 \\
\text { months }\end{array}$ & $\begin{array}{l}\text { NSD }^{\#} \text { after } 1-3 \text { years } \\
\text { improved } 2 \text { years OS ( } 46 \% \text { vs. } 4 \%) \text { in }{ }^{89} \mathrm{Sr} \text { arm }\end{array}$ \\
\hline \multirow{2}{*}{$\begin{array}{lr}\text { Adjuvant } & { }^{89} \mathrm{Sr} \\
\text { compared } & \text { to } \\
\text { placebo } & \end{array}$} & $\begin{array}{l}\text { Porter et al. } \\
\text { (Phase III) [16] }\end{array}$ & $\begin{array}{l}{ }^{89} \mathrm{Sr} \text { as adjunctive therapy } \\
\text { to local XRT compared } \\
\text { with placebo }\end{array}$ & 126 & $\begin{array}{l}\text { Involved field } \mathrm{XRT} \\
\text { and } 10.8 \mathrm{mCi} \\
\mathrm{MBq}) \text { injection }\end{array}$ & $\begin{array}{l}\text { Fewer new pain sites in }{ }^{89} \mathrm{Sr} \text { group } \\
\text { NSD pain relief or median survival. }{ }^{89} \mathrm{Sr} \text { arm better in need of } \\
\text { analgesics, time to further XRT and further quality of life. }\end{array}$ \\
\hline & $\begin{array}{l}\text { Smeland et al. } \\
\text { (phase III) [17]. }\end{array}$ & $\begin{array}{l}\mathrm{EBRT}+{ }^{89} \mathrm{Sr} \text { vs. } \\
\mathrm{EBRT}+\text { placebo }\end{array}$ & $\begin{array}{lr}95 & (64 \\
\text { prostate })\end{array}$ & $150 \mathrm{MBq}$ & $\begin{array}{l}\text { No adjuvant benefit to }{ }^{89} \mathrm{Sr} \text { with EBRT } \\
\text { No survival or QOL, PSA difference }\end{array}$ \\
\hline \multirow{2}{*}{$\begin{array}{l}{ }^{89} \mathrm{Sr} \text { compared } \\
\text { to EBRT }\end{array}$} & $\begin{array}{l}\text { Quilty et al. } \\
\text { (stratum I) Phase } \\
\text { III [19]. }\end{array}$ & $\begin{array}{l}{ }^{89} \mathrm{Sr} \text { with EBRT (involved } \\
\text { field) }\end{array}$ & 148 & $200 \mathrm{MBq}$ & $\begin{array}{l}\text { NSD in pain relief or survival, decreased new sites and further } \\
\text { XRT. }\end{array}$ \\
\hline & $\begin{array}{l}\text { Quilty et al. } \\
\text { (stratum II) Phase } \\
\text { III [19] }\end{array}$ & $\begin{array}{l}{ }^{89} \mathrm{Sr} \quad \text { with } \\
\text { (hemibody RT) }\end{array}$ & 157 & $\begin{array}{l}200 \mathrm{MBq} \text { vs. } 6 \mathrm{~Gy} \\
\text { upper, } 8 \text { Gy lower }\end{array}$ & $\begin{array}{l}\text { NSD in pain relief or median survival } \\
{ }^{89} \mathrm{Sr} \text { reduced new pain sites }\end{array}$ \\
\hline
\end{tabular}

Alpha particles from ${ }^{223}$ Ra have a high linear energy transfer (LET) is relatively ineffective in overcoming the radio-resistance of hypoxic tumor cells compared to oxygenated cells [10]. High-energy LET radiation ( $\alpha$ rays) overcomes this radio-resistance compared to low LET therapies due to its low oxygen enhancement ratio. For a given absorbed dose, $\alpha$ radiation also has a higher relative biological effect (RBE), achieving a greater cell kill per dose compared with low LET treatments. To produce the same cell kill as a particles, it is estimated that at least 100 to 1000 times the number of $\beta$ particles are required [11]. BT-RNT using a emitters also have theoretical benefits in using more than one treatments as the DNA damage induced by a particles takes longer to repair and therefore gives a high probability of accumulated damage with each treatment $[10,11]$. Repeat cycles of ${ }^{223} \mathrm{Ra}$ can result in progressive tumour cell killing. Analogous to fractionated external radiotherapy cancer cells with residual DNA damage may be eradicated by subsequent treatment courses with radioisotope.

Particle range influences treatment-related toxicity. Usually the energy of shorter range particles is largely absorbed within the target cell, whereas longer-range particles may irradiate more surrounding healthy tissues like bone marrow, contributing to unwanted toxicity. The physical characteristics of therapeutic radionuclides for bone pain palliation are summarized in Table $1[4,12,13]$.

\section{Clinical Endpoints of BT-RNT Therapy}

Palliation of bone pain remains the main clinical indication for BTRNT. Up to $70 \%$ of patients experience pain relief and approximately $20 \%$ experience complete pain resolution. Published clinical trials measure pain differently and hence it is difficult to cross compare studies. In addition, many of the trials had relatively small patient numbers (18). Evidence supporting the use of different radiopharmaceuticals is discussed here, and administered activities, typical responses, and re-treatment intervals are listed in Table 2 [14-29]. compared to agents which emit $\beta$ rays (lower LET). Low LET radiation 
Citation: Nair VJ, Malone C, Moretto P, Leung E, Malone S (2014) Bone-Seeking Targeted Radio-Nuclide Therapy (BT-RNT) in Management of Metastatic Castration-Resistant Prostate Cancer (mCRPC): Shifting from Palliation to Improving Survival. J Nucl Med Radiat Ther 6: 202. doi:10.4172/2155-9619.1000202

Page 4 of 8

\begin{tabular}{|c|c|c|c|c|c|}
\hline & $\begin{array}{l}\text { Oosterhof et al., } \\
\text { Phase III [20]. }\end{array}$ & EBRT vs. ${ }^{89} \mathrm{Sr}$ & 203 & $150 \mathrm{MBq}(4 \mathrm{mCi})$ & $\begin{array}{l}\text { Better OS with XRT (11 months vs. } 7.2 \text { months) } \\
\text { No difference in PSA response }\end{array}$ \\
\hline${ }^{89} \mathrm{Sr}$ vs. ${ }^{153} \mathrm{Sm}$ & Baczyk et al. [21] & ${ }^{89} \mathrm{Sr}$ vs. $153 \mathrm{Sm}$ & 50 & $\begin{array}{l}{ }^{89} \mathrm{Sr}(150 \mathrm{MBq}) \text { vs. } \\
153 \mathrm{Sm}(37 \mathrm{MBq} \text { per } \\
\mathrm{kg})\end{array}$ & $\begin{array}{l}\text { NSD pain relief. Better response for blastic metastasis than } \\
\text { mixed. }\end{array}$ \\
\hline \multirow{2}{*}{$\begin{array}{l}{ }^{89} \mathrm{Sr} \quad \text { vs. } \\
\text { chemotherapy } \\
\text { alone }\end{array}$} & Tu et al. [22] & $\begin{array}{l}\text { Induction chemo followed } \\
\text { by randomisation to } \\
\text { doxorubicin with or } \\
\text { without } 6 \text { weekly }{ }^{89} \mathrm{Sr} 89\end{array}$ & 72 & $2.035 \mathrm{MBq}$ per $\mathrm{kg}$ & $\begin{array}{l}\text { Significant survival advantage for addition of }{ }^{89} \mathrm{Sr} \text { ( } 27.7 \text { vs. } 16.8 \\
\text { mo) }\end{array}$ \\
\hline & Nilsson et al. [23] & $\begin{array}{l}{ }^{89} \mathrm{Sr}(18) \text { vs. } 5-\mathrm{FU}, \\
\text { epirubicin, } \\
\text { mitomycin-C }\end{array}$ & 35 & $150 \mathrm{MBq}(4 \mathrm{mCi})$ & $\begin{array}{l}\text { At } 3 \text { weeks, pain reduced in both groups }(p=0.01 \text { and } 0.001 \\
\text { respectively) } \\
\text { No differences in Karnofsky performance status or analgesic } \\
\text { use } \\
\text { More side effects in the chemo arm. }\end{array}$ \\
\hline \multirow{2}{*}{$\begin{array}{l}{ }^{153} \mathrm{Sm} \\
\text { placebo }\end{array}$} & Serafini et al. [24] & ${ }^{153} \mathrm{Sm}$ vs. placebo & 118 & $\begin{array}{ll}0.5-1 & \mathrm{mCi} / \mathrm{kg} \\
(18.5-37 & \\
\mathrm{MBq} / \mathrm{kg}) & \end{array}$ & $\begin{array}{l}62-72 \% \text { of patients had Ipain relief with } 1.0 \mathrm{mCi} / \mathrm{kg} \text { during first } \\
4 \text { weeks and } 31 \% \text { had complete/ marked relief by week } 4\end{array}$ \\
\hline & Sartor et al. [25] & $\begin{array}{l}{ }^{153} \mathrm{Sm}(101) \text { vs. } \\
\text { placebo }(51)\end{array}$ & 152 & $\begin{array}{l}1 \underset{\mathrm{MBq} / \mathrm{kg})}{\mathrm{mCi} / \mathrm{kg}} \quad(37 \\
\end{array}$ & $\begin{array}{l}\text { Significant improvement in bone pain and analgesic use with } \\
\text { Sm-153 }(p<0.05)\end{array}$ \\
\hline $\begin{array}{l}{ }^{153} \mathrm{Sm} \quad 0.5 \mathrm{vs} . \\
1.0\end{array}$ & Resche et al. [26] & $\begin{array}{l}{ }^{153} \mathrm{Sm} \text { at } 0.5 \mathrm{mCi} / \\
\mathrm{kg}(55) \text { vs. } 1.0 \mathrm{mCi} / \\
\mathrm{kg}(59)\end{array}$ & $\begin{array}{l}114 \quad(67 \\
\text { prostate) }\end{array}$ & $\begin{array}{l}{ }^{153} \mathrm{Sm} \text { at } 0.5 \mathrm{mCi} / \\
\mathrm{kg}(55) \text { vs. } 1.0 \mathrm{mCi} / \\
\mathrm{kg}(59)\end{array}$ & $\begin{array}{l}55 \% \text { vs. } 70 \% \text { pain relief between } 0.5 \mathrm{mc} 9 \text { and } 1.0 \mathrm{mci} \text { at week } \\
4(\mathrm{p}=0.0476) \\
\text { OS not different between groups }\end{array}$ \\
\hline \multirow[t]{2}{*}{$\begin{array}{l}{ }^{186} \mathrm{Re} \\
\text { placebo }\end{array}$} & $\begin{array}{l}\text { Han et al. Phase } \\
\text { III [27] } \\
\text { (PLACORHEN } \\
\text { study) }\end{array}$ & ${ }^{186}$ Re vs. Placebo & 79 & $\begin{array}{l}1,295 \text { to } 2,960 \mathrm{MBq} \\
(35-80 \mathrm{mCi})\end{array}$ & $\begin{array}{l}\text { Mean percentage of pain response days } 27 \%\left({ }^{186} \mathrm{Re}\right) \text { vs. } 13 \% \\
\text { (placebo), } p<0.05 \\
\text { Median survival } 37.2 \text { weeks (placebo) vs. } 30.4 \text { weeks }\left({ }^{186} \mathrm{Re}\right) \text {, } \\
p>0.05 \\
\begin{array}{l}\text { Radiotherapy for pain required in } 44 \%\left({ }^{186} \mathrm{Re}\right) \text { vs. } 67 \% \\
\text { (placebo) }\end{array}\end{array}$ \\
\hline & \begin{tabular}{ll|} 
Maxon et al. & \\
Phase & III \\
crossover [28]
\end{tabular} & $\begin{array}{l}{ }^{186} \operatorname{Re}(6) \\
\text { vs. Placebo }\end{array}$ & $\begin{array}{l}20 \quad(9 \\
\text { prostate) }\end{array}$ & $\begin{array}{l}30-35 \quad \mathrm{mCi} \\
(1110-1295 \mathrm{MBq})\end{array}$ & $\begin{array}{l}\text { Significantly greater relief in pain with }{ }^{186} \operatorname{Re}(p<0.05) \text {. Higher } \\
\text { leukopenia in } R e \text { arm }\end{array}$ \\
\hline $\begin{array}{ll}{ }^{223} \mathrm{Ra} & \text { vs. } \\
\text { placebo }\end{array}$ & $\begin{array}{l}\text { Parker et al. [29] } \\
\text { Phase III } \\
\text { (ALSYMPCA } \\
\text { trial) }\end{array}$ & $\begin{array}{l}{ }^{223} \mathrm{Ra}(541) \text { vs. } \\
\text { placebo }(268)\end{array}$ & 809 & $\begin{array}{l}(50 \mathrm{kBq} / \mathrm{kg} \\
\text { weeks }\end{array}$ & $\begin{array}{l}\text { OS: } 14 \text { months }\left({ }^{223} \mathrm{Ra}\right) \text { vs. } 11.2 \text { months (placebo), HR } 0.695, p \\
=0.001 \mathrm{HR} \text { time to total ALP progression: } 0.163(p<0.00001) \text {, } \\
\text { HR for time to PSA progression: } 0.671(p=0.0002) \text {, }\end{array}$ \\
\hline
\end{tabular}

Table 2: Table demonstrating the various randomised trials in bone seeking radionuclide therapy. ${ }^{\#}$ No significant difference.

As we gain more insight into these agents there is great interest in studying clinical predictors of response to therapy. An Italian multicenter observational study in metastatic prostate cancer patients found that patients with limited skeletal disease, radiologically osteoblastic or mixed bone lesions, life expectancy more than 3 months had better responses with BT-RNTs. The flare phenomenon which was found in $14 \%$ patients did not correlate with response [30]. Zafeirakis et al. found that NTx, a potent collagenous marker of bone resorption, along with the novel NTx/PINP (N-telopeptide/ aminoterminal propeptide of type I collagen) ratio provide useful cutoff values for identifying a group of castrate-resistant prostate cancer patients who do not respond to palliative treatment with ${ }^{186}$ Re-HEDP [31].

Even though radionuclide dose escalation studies have reported a dose response relationship, increasing myelotoxicity is also seen with higher doses. Due to this dose-limiting toxicity of myelosuppression, clinical trials combining BT-RNT with stem cell support are also being studied [32,33]. Nilsson et al. in their dose escalation study for ${ }^{233} \mathrm{Ra}$ also reports increasing response for pain control with increasing dose of ${ }^{233} \mathrm{Ra}$ with minimal toxicity even at the highest dose level [1]. Additional trials of dose escalation and extended duration ${ }^{233} \mathrm{Ra}$ are underway to evaluate safety and potential benefits.

The disease modifying properties of BT-RNT agents are a matter of interest as they may be useful surrogate markers of clinical benefit of therapy. In evaluating new treatment options for mCRPC serum biomarkers, such as PSA and bone ALP, are commonly used as early efficacy markers. Reduction in markers of bone turnover such as alkaline phosphatase have been reported with BT-RNT, however it is unclear whether this is due to an anti-tumor response or whether these marker changes simply reflect a modulation of the metastasis-induced bone dysregulation or due to direct toxicity to the osteoblasts $[1,16,34]$. A phase II randomised study demonstrated that ${ }^{223} \mathrm{Ra}$ therapy produced $>50 \%$ reduction in bone ALP in $16-66 \%$ patients depending on the administered dose [35]. Some trials demonstrate a 
Citation: Nair VJ, Malone C, Moretto P, Leung E, Malone S (2014) Bone-Seeking Targeted Radio-Nuclide Therapy (BT-RNT) in Management of Metastatic Castration-Resistant Prostate Cancer (mCRPC): Shifting from Palliation to Improving Survival. J Nucl Med Radiat Ther 6: 202. doi:10.4172/2155-9619.1000202

Page 5 of 8

reduction in PSA levels in prostate cancer patients in response to BTRNT [36]. In the pivotal TAX327 chemotherapy trial, ALP normalization at 90 days occurred in $26 \%$ of patients receiving docetaxel or mitoxantrone and correlated with better survival, independent of $\geq 30 \%$ PSA declines. The ALSYMPCA trial also showed improved survival with ${ }^{223} \mathrm{Ra}$ in a phase III setting for mCRPC [22,37-39].

Specific clinical considerations for the various BT-RNT are listed below.

\section{Phosphorus 32, ${ }^{32} \mathbf{P}$}

Oral or injectable ${ }^{32} \mathrm{P}$ (usually injectable sodium orthophosphate) is now rarely used due to its high incidence of myelotoxicity. In addition to tin, radiophosphorus has only been investigated in phase I/II trials in metastatic prostate cancer at this time [37].

\section{Strontium $89,{ }^{89} \mathrm{Sr}-\mathrm{Cl}$ (Metastron $\left.{ }^{\circ}\right)$}

Strontium-89 chloride was FDA approved in 1993 as the first betaemitting radiopharmaceutical for metastatic prostate cancer. ${ }^{89} \mathrm{Sr}$ has been evaluated in phase III trials for mCRPC. Due to its biological half-life, the toxicity profile is much better than ${ }^{32} \mathrm{P} .{ }^{89} \mathrm{Sr}$ has proven efficacy in the palliation of painful bony metastases in mCRPC. (Table 2) ${ }^{89} \mathrm{Sr}$ monotherapy has not been shown to lengthen the average duration of patient survival. The evidence favoring combination of ${ }^{89} \mathrm{Sr}$ with chemotherapy is demonstrated in Table 2 . The recommended dose for ${ }^{89} \mathrm{Sr}$ is $148 \mathrm{MBq}(4 \mathrm{mCi})$ by slow intravenous injection (1-2 minutes), accompanied by intravenous or oral hydration (at least $500 \mathrm{~mL}$ ) [37]. Onset of pain relief is generally 7-20 days. Excretion is through urine (67\%) and feces (33\%).

\section{Samarium 153, ${ }^{153}$ Sm-EDTMP (Quadramet $\left.{ }^{\circ}\right)$}

Samarium 153 lexidronam is currently licensed in Canada, and has been available since 2013. The recommended dose for ${ }^{153} \mathrm{Sm}$ is 37 $\mathrm{MBq} / \mathrm{kg}(1 \mathrm{mCi} / \mathrm{kg})$ by slow intravenous injection (1-2 minutes), accompanied by intravenous or oral hydration (at least $500 \mathrm{~mL}$ ) [38]. Table 2 shows the randomised trials demonstrating the benefits of this radionuclide over placebo. Myelotoxicity is less than with strontium-89.

\section{Radium-223 ( $\left.{ }^{223} \mathrm{Ra}\right) ;{ }^{223} \mathrm{Ra}-\mathrm{Cl}$ (Xofigo $\left.{ }^{\circ}\right)$}

Radium-223 chloride (Xofigo", Bayer), formerly known as Alpharadin ${ }^{\circ}$ is a calcium mimetic, bone-seeking agent that targets new bone growth within and around metastases. ${ }^{223} \mathrm{Ra}$ emits high-energy alpha-particles within a 2 - to 10 -cell diameter distance, generating highly localized and intense radiation zones that induce primarily non-repairable, double stranded DNA breaks in the target areas containing metastatic cancer cells. The relatively favorable safety profile of ${ }^{223} \mathrm{Ra}$ has been demonstrated in phase I, II, and III studies of patients with bone metastases [1].

Importantly, ${ }^{223} \mathrm{Ra}$ is the first agent in this class to show an overall survival advantage in mCRPC patients with bone metastases. The recent phase III ALSYMPCA (ALpharidin in SYMptomatic Prostate Cancer) trial demonstrated an overall survival benefit compared to placebo; the trial was stopped prematurely after an interim analysis had shown an improvement in overall survival (14.9 month vs. 11.3 months), in addition to reduced frequency of SREs and increased median time to an SRE (15.6 vs. 9.8 months). The toxicity profile was favourable with low rates of bone marrow toxicity in the form of grade 3 or 4 neutropenia $1.8 \%$ vs. $0.8 \%$ and thrombocytopenia rates $4 \%$ vs. $2 \%$ compared to the placebo arm $[29,40] .{ }^{223} \mathrm{Ra}$ was approved by FDA on May 13, 2013 for the treatment of patients with castration-resistant prostate cancer, symptomatic bone metastases and no known visceral metastatic disease [39]. ${ }^{223} \mathrm{Ra}$ received Health Canada approval in December 2013. Thus, ${ }^{223} \mathrm{Ra}$ is the first bone-targeted agent shown to meaningfully alter the natural history of mCRPC. In addition ${ }^{223} \mathrm{Ra}$ provided palliation of pain, quality of life benefits, delayed SRE's and had a favourable toxicity profile.

\section{Rhenium-186 ( ${ }^{186}$ Re-HEDP) and Rhenium-188 $\left({ }^{188}\right.$ Re- HEDP)}

Rhenium is a transitional metal with two radioisotopes (Re-186 and Re-188) that can be attached to hydroxyethylidene diphosphonate (HEDP) for bone targeting. The PLACORHEN randomized controlled trial of ${ }^{186}$ Re-HEDP vs placebo showed a significantly higher rate of pain responders (65\% vs. $36 \%$, respectively). The number of patients in this study requiring palliative EBRT was higher in the placebo group than in the treatment group (67\% vs. $44 \%)$. Repeat administration of ${ }^{186}$ Re-HEDP appears to be both safe and effective in select patients $[27,40] .{ }^{188} \mathrm{Re}-(\mathrm{Sn}) \mathrm{HEDP}$ has similar bio-distribution and radiation dosimetry characteristics as ${ }^{186} \mathrm{Re}-(\mathrm{Sn}) \mathrm{HEDP}$ and appears to result in similar benefits and toxicities in patients with skeletal metastases. An advantage of Re-188 is that this radionuclide can be produced in a relatively convenient generator. More data on the effectiveness of $\mathrm{Re}-188$ is needed [41].

\section{Tin-117(stannic, 4+) DTPA (Sn-117m DTPA)}

The metastable isotope ${ }^{117} \mathrm{mSn}$, chelated to diethylenetriamine pentaacetic acid (DTPA), is under investigation as a possible therapeutic radionuclide for the treatment of bone metastases. The range of electron emission is less than any other compound (micrometers), hence potentially less marrow dose. The half-life of 13.6 days is ideal as far as shipment and shelf life is concerned. Tin is a natural bone-seeker, but its highest specificity for bone occurs when the element is in its quatravalent state (4+). DTPA stabilizes tin in this preferred $4+$ state, protecting it from competing redox reactions in vivo. There is also accompanying gamma photons which can be used for monitoring distributions. Preliminary clinical studies have shown promise [13].

Other investigational agents such as Lutetium-177 $\left({ }^{177} \mathrm{Lu}\right)$, Thulium-170 $\left({ }^{170} \mathrm{Tm}\right)$ are also under clinical study.

\section{Indications}

The indications for BT-RNT are treatment of symptomatic multiple skeletal metastasis of blastic or mixed type with intense uptake around painful metastases. The indications and contraindications of BT-RNTs are demonstrated in Table 3. Most common reason for failure of therapy is inappropriate patient selection. Foci of increased uptake on bone scan should be confirmed and correlated with patient's symptoms to attribute to osteoblastic metastases, since other pain aetiologies such as vertebral collapse, nerve root entrapment, fracture or visceral pain will not respond to BT-RNT. In patients with predominantly osteolytic pattern of skeletal metastases, the response may be less favourable due to the poor uptake and retention resulting in lower metastatic absorbed dose. 
Citation: Nair VJ, Malone C, Moretto P, Leung E, Malone S (2014) Bone-Seeking Targeted Radio-Nuclide Therapy (BT-RNT) in Management of Metastatic Castration-Resistant Prostate Cancer (mCRPC): Shifting from Palliation to Improving Survival. J Nucl Med Radiat Ther 6: 202. doi:10.4172/2155-9619.1000202

Page 6 of 8

\begin{tabular}{|c|c|}
\hline Indications & Contra-Indications \\
\hline $\begin{array}{l}\text { Known castrate-resistant prostate cancer with painful bone metastasis } \\
\text { Metastatic disease refractory to hormone therapy } \\
\text { Severe pain poorly controlled with conventional narcotics } \\
\text { Not a candidate for local or wide field radiotherapy } \\
\text { Positive correlation between pain sites and osteoblastic lesions on bone scan } \\
\text { Painful sites of disease on both sides of the diaphragm } \\
\text { No chemotherapy or large field radiation in the past } 4-12 \text { weeks } \\
\text { Urinary catheter placed for incontinence } \\
\text { Life expectancy more than } 4 \text { weeks } \\
\text { Signed informed consent } \\
\text { Adequate bone marrow reserve } \\
\text { - Hemoglobin }>9.0 \mathrm{mg} / \mathrm{dl} \\
\text { - Absolute WBC }>3500 / \mathrm{dl} \\
\text { - Absolute neutrophil }>1500 / \mathrm{dl} \\
\text { Platelets }>1,00,000 / \mathrm{dl} \\
\text { Glomerular filtration rate }>50 \mathrm{Ml} / \mathrm{min} \text {; urea }<12 \mathrm{mmol} / \mathrm{L} \text {; creatinine }<200 \mathrm{mmol} / \mathrm{L}\end{array}$ & $\begin{array}{l}\text { Absolute pregnancy, continuing breast feeding. } \\
\text { History of hypersenstitivty to EDTMP or similar phosphonate compounds } \\
\text { Relative myelosuppression chronic renal failure or deterioration of renal } \\
\text { function (urea }>12 \mathrm{mmol} / / \text {; creatinine }>150 \mathrm{mmol} / / \text {; GFR }<30 \mathrm{~mL} / \mathrm{min} \text { ) } \\
\text { urinary incontinence } \\
\text { acute or chronic spinal cord compression and/or metastases at the base of the } \\
\text { skull }\end{array}$ \\
\hline
\end{tabular}

Table 3: Criteria for patient selection for bone-seeking radionuclide therapy.

Preserved renal function is vital in clearance of most of these agents. Elderly mCRPC patients can present with modest renal impairment, so the benefits vs. risks in these patients should be carefully considered. The outflow obstruction at vesico-ureteric junction or bladder neck should be treated appropriately before BT-RNT administration. Incontinent patients may require urinary catheterization [39]. ${ }^{223} \mathrm{Ra}$ is predominantly excreted by the GI tract and does not impact on renal function. The 2013 AUA guidelines state that radionuclide therapy may be offered to patients with symptomatic mCRPC who do not want or cannot have one of the standard therapies [42]. However, these guidelines did not consider the use of ${ }^{223} \mathrm{Ra}$ which has disease modifying effect as indicated by an improved survival and delay in Skeletal Related Events.

\section{Administration and Side Effects of BT-RNT}

Generally the treatment is an outpatient based; since particle emissions are attenuated within the patient specific radiation isolation is unnecessary and universal precautions similar to those use with chemotherapy are employed. Some centres observe overnight with or without hydration. Patients should be well hydrated prior to procedure to allow for sufficient elimination of residual radionuclide. After the intravenous administration of the agent, the patient typically is followed with frequent blood counts monitoring up to 8 weeks [43].

The principal side effect of BT-RNT in general is myelosuppression, with thrombocytopenia being the most common form. Anemia and neutropenia are less common. Flare phenomenon is usually seen in $5-10 \%$ patients which is a transient and self-limiting increase in bone pain, especially in patients with high tumor burden. This usually occurs 36-72 hours post dose and the reaction is generally mild and self-limiting. Other toxicity include loose stools, nausea, asymptomatic hematuria and heart palpitations. Some patients may notice a flushing sensation following rapid $(<30 \mathrm{sec})$ injection of Sr89 [43].

In the ALSYMPCA trial, the noted side effects were nausea, diarrhea, vomiting and swelling of the leg, ankle or foot. The most common abnormalities detected during blood testing were anemia, lymphocytopenia, leukopenia, thrombocytopenia and neutropenia.
The haematological toxicity was less compared to the other agents $[29,39]$. There were no effects of [39] ${ }^{223} \mathrm{Ra}$ on renal function as it is predominantly excreted by the GI tract.

\section{Combination with Other Prostate Cancer Therapies}

\section{Chemotherapy}

Chemotherapy is known to have a synergistic effects with radiation therapy as it makes the cancer cells more susceptible to damage by radiation. Most clinical trials studying combination of chemotherapy and BT-RNT used Sr-89 as the agent. However there is no published randomised phase III trial. Sciuto et al. showed that the pain response in patients treated with $\mathrm{Sr}-89$ and low dose carboplatin was superior to Sr-89 alone in terms of longer duration of pain control [44]. Small series studying low-dose cisplatin in combination with ${ }^{89} \mathrm{Sr}$ showed improved response rates compared to Sr-89 monotherapy [18]. The phase I/II Taxium trial using fractionated ${ }^{186} \mathrm{Re}-\mathrm{HEDP}$ and 3-weekly docetaxol may give some more evidence regarding the effectiveness of this combination [45]. Phase I trials combining ${ }^{153} \mathrm{Sm}$ with weekly docetaxel and 3-weekly docetaxel showed the combination to be well tolerated [46,47]. Numerous phase II trials in mCRPC showed that ${ }^{89} \mathrm{Sr}$ or ${ }^{153} \mathrm{Sm}$ in combination with chemotherapy improved outcomes in a subset of patients $[48,49]$. However with newer agents like ${ }^{223} \mathrm{Ra}$, which has better bone marrow preservation there is potential for designing clinical trials in combination with chemotherapy. The results of the ongoing phase I/IIa study of ${ }^{223} \mathrm{Ra}$ and docetaxel for mCRPC would be able to provide insights on this [50]. More evidence needs to be gathered regarding the best agents and dose regimens that need to be combined to balance toxicity and outcomes.

\section{Radiotherapy}

Porter et al. showed that the addition of Sr- 89 to external beam radiotherapy was associated with lower pain scales and analgesic consumption, as well as a longer interval to the development of new sites of painful bone metastases, compared to local field radiotherapy alone in patients with mCRPC. However this study was criticised due 
Citation: Nair VJ, Malone C, Moretto P, Leung E, Malone S (2014) Bone-Seeking Targeted Radio-Nuclide Therapy (BT-RNT) in Management of Metastatic Castration-Resistant Prostate Cancer (mCRPC): Shifting from Palliation to Improving Survival. J Nucl Med Radiat Ther 6: 202. doi:10.4172/2155-9619.1000202

Page 7 of 8

to the higher ${ }^{89} \mathrm{Sr}$ doses used [36]. No other trial could demonstrate this benefit [17]. This form of combination potentially helps to give extra radiation doses to larger lesions that could be radiologically localised. In a sub-analyses of ALSYMPCA it was safe to give subsequent palliative radiation to patients who have received prior ${ }^{223} \mathrm{Ra}$.

\section{Combination with bisphosphonates}

The hypothesis against concomitant use is that the competitive interaction of bisphosphonates and the radionuclide at the hydroxyapatite crystal surface of the skeleton, could decrease the uptake and clinical effect of both agents. However the clinical evidence regarding combining bisphosphonates with BT-RNT is conflicting [6] Storto et al., in his retrospective study, showed that sequential use of Sr-89 with zolendronic acid compared to $\mathrm{Sr}-89$ alone demonstrated higher response rates in the form of reduced analgesic doses in the combined arm (96\% vs. $76 \%)$ at the end of 6 months of therapy. The bone marrow toxicity was also slightly higher but tolerable [51] However the evidence with newer agents like ${ }^{223} \mathrm{Ra}$ is still unknown. ${ }^{223} \mathrm{Ra}$ resulted in a survival advantage in patients There was comparable survival benefit for those patients who were receiving bisphosphonates vs. those patients those who were not receiving bisphosphonates in the ALSYMPCA Trial.

\section{Re-treatment using BT-RNTs}

The role for repeat administration of BT-RNT is of interest in palliation of patients with mCRPC patients who have exhausted all other treatment options. Multiple administrations of Re-188 showed an improved overall survival compared to single administration in mCRPC [52]. The feasibility of repeating ${ }^{153} \mathrm{Sm}$ therapy in mCRPC who were previous responders to therapy has been shown. The same study also showed that the magnitude of response remained the same with each dosing [25]. Due to reduced bone marrow toxicity, the use of repeat ${ }^{223} \mathrm{Ra}$ seems attractive and future trials will evaluate its safety and efficacy.

\section{Conclusion}

BT-RNT is an effective treatment option for pain palliation in patients with mCRPC. Xofigo $\left.{ }^{\circ}{ }^{223} \mathrm{Ra}\right)$ is an exciting new systemic radionuclide therapy which improves survival in mCRPC. It has a favourable safety profile and has been shown to improving quality of life and delay skeletal related events. Additional clinical trials are necessary to expand on the emerging positive evidence with Xofigo $\left({ }^{223} \mathrm{Ra}\right)$ as monotherapy as well as in combination with other systemic therapies to further improve patient outcomes.

Supported by The Ottawa Hospital Foundation, Author VJN was funded by The Ethel Ward Cushing Legacy Endowment Fund for a stereotactic ablative radiotherapy fellowship.

\section{References}

1. Nilsson S, Franzén L, Parker C, Tyrrell C, Blom R, et al. (2013) Two-year survival follow-up of the randomized, double-blind, placebo-controlled phase II study of radium-223chloride in patients with castration-resistant prostate cancer and bone metastases. Clin Genitourin Cancer 11: 20-26.

2. Harrison MR, Wong TZ, Armstrong AJ, George DJ (2013) Radium-223 chloride: a potential new treatment for castration-resistant prostate cancer patients with metastatic bone disease. Cancer Manag Res 5: 1-14.
3. Keller ET, Brown J (2004) Prostate cancer bone metastases promote both osteolytic and osteoblastic activity. J Cell Biochem 91: 718-729.

4. Lewington VJ (2005) Bone-seeking radionuclides for therapy. J Nucl Med 46 Suppl 1: 38S-47S.

5. Pecher C (1942) Biological investigation with radioactive calcium and strontium: preliminary report on the use of radioactive strontium in the treatment of metastatic bone cancer. Univ Calif Publ Pharmacol 2: 117149.

6. Paes FM, Serafini AN (2010) Systemic metabolic radiopharmaceutical therapy in the treatment of metastatic bone pain. Semin Nucl Med 40: 89-104.

7. Bruland ØS, Nilsson S, Fisher DR, Larsen RH (2006) High-linear energy transfer irradiation targeted to skeletal metastases by the alpha-emitter 223Ra: adjuvant or alternative to conventional modalities? Clin Cancer Res.12: 6250s-6257s.

8. Tu SM, Lin SH, Podoloff DA, Logothetis CJ (2010) Multimodality therapy: bone-targeted radioisotope therapy of prostate cancer. Clin Adv Hematol Oncol 8: 341-351.

9. Britton KE (1999) Current trends in radionuclide therapy. In IAEA (2001)-TECDOC-1228. "Therapeutic Applications of Radiopharmaceuticals". Proceedings of an International Seminar held in Hyderabad, India.

10. Ma N, Tinganelli W, Maier A, Durante M, Kraft-Weyrather W (2013) Influence of chronic hypoxia and radiation quality on cell survival. Radiat Res. 54: i13-i22.

11. Sgouros G, Roeske JC, McDevitt MR, Palm S, Allen BJ, et al. (2010) MIRD Pamphlet No. 22 (abridged): radiobiology and dosimetry of alphaparticle emitters for targeted radionuclide therapy. J Nucl Med 51: 311-328.

12. Srivastava SC, Atkins HL, Krishnamurthy GT, Zanzi I, Silberstein EB, et al. (1998) Treatment of metastatic bone pain with tin-117m Stannic diethylenetriaminepentaacetic acid: a phase I/II clinical study. Clin Cancer Res 4: 61-68.

13. Srivastava SC (2007) The role of electron-emitting radiopharmaceuticals in the palliative treatment of metastatic bone pain and for radiosynovectomy: applications of conversion electron emitter Tin-117m. Braz. arch. biol. technol. 50: 49-62.

14. Lewington VJ, McEwan AJ, Ackery DM, Bayly RJ, Keeling DH, et al. (1991) A prospective, randomised double-blind crossover study to examine the efficacy of strontium-89 in pain palliation in patients with advanced prostate cancer metastatic to bone. Eur J Cancer (Oxford, England:1990) 27: 954-958.

15. Buchali K, Correns HJ, Schuerer M, Schnorr D, Lips H, et al. (1988) Results of a double blind study of 89-strontium therapy of skeletal metastases of prostatic carcinoma. Eur J Nucl Med 14: 349-351.

16. Porter AT, McEwan AJ, Powe JE, Reid R, McGowan DG, et al. (1993) Results of a randomized phase-III trial to evaluate the efficacy of strontium-89 adjuvant to local field external beam irradiation in the management of endocrine resistant metastatic prostate cancer. Int J Radiat Oncol Biol Phys 25: 805-813.

17. Smeland S, Erikstein B, Aas M, Skovlund E, Hess SL, et al. (2003) Role of strontium-89 as adjuvant to palliative external beam radiotherapy is questionable: results of a double-blind randomized study. Int J Radiat Oncol Biol Phys 56: 1397-1404.

18. Brady D, Parker CC, O'Sullivan JM (2013) Bone-targeting radiopharmaceuticals including radium-223. Cancer J 19: 71-78.

19. Quilty PM, Kirk D, Bolger JJ, Dearnaley DP, Lewington VJ, et al. (1994) A comparison of the palliative effects of strontium-89 and external beam radiotherapy in metastatic prostate cancer. Radiother Oncol 31: 33-40.

20. Oosterhof GON, Roberts JT, de Reijke TM, Engelholm SA, Horenblas S, et al. (2003) Strontium89 chloride versus palliative local field radiotherapy in patients with hormonal escaped prostate cancer: a phase III study of the European Organisation for Research and Treatment of Cancer Genitourinary Group. Eur Urol. 44: 519-526.

21. Baczyk M, Czepczy $\AA$,ski R, Milecki P, Pisarek M, Oleksa R, et al. (2007) $89 \mathrm{Sr}$ versus 153Sm-EDTMP: comparison of treatment efficacy of painful 
Citation: Nair VJ, Malone C, Moretto P, Leung E, Malone S (2014) Bone-Seeking Targeted Radio-Nuclide Therapy (BT-RNT) in Management of Metastatic Castration-Resistant Prostate Cancer (mCRPC): Shifting from Palliation to Improving Survival. J Nucl Med Radiat Ther 6: 202. doi:10.4172/2155-9619.1000202

Page 8 of 8

bone metastases in prostate and breast carcinoma. Nucl Med Commun 28: $245-250$.

22. Tu SM, Millikan RE, Mengistu B, Delpassand ES, Amato RJ, et al. (2001) Bone-targeted therapy for advanced androgen-independent carcinoma of the prostate: a randomised phase II trial. Lancet 357: 336-341.

23. Nilsson S, Strang P, Ginman C, Zimmermann R, Edgren M, et al. (2005) Palliation of bone pain in prostate cancer using chemotherapy and strontium-89. A randomized phase II study. J Pain Symptom Manage 29: 352-357.

24. Serafini AN, Houston SJ, Resche I, Quick DP, Grund FM, et al. (1998) Palliation of pain associated with metastatic bone cancer using samarium-153 lexidronam: a double-blind placebo-controlled clinical trial. J Clin Oncol 16: 1574-1581.

25. Sartor O, Reid RH, Hoskin PJ, Quick DP, Ell PJ, et al. (2004) Samarium-153-Lexidronam complex for treatment of painful bone metastases in hormone-refractory prostate cancer. Urology 63: 940-945.

26. Resche I, Chatal JF, Pecking A, Ell P, Duchesne G, et al. (1997) A dosecontrolled study of $153 \mathrm{Sm}$-ethylenediaminetetramethylenephosphonate (EDTMP) in the treatment of patients with painful bone metastases. Eur J Cancer 33: 1583-1591.

27. Han SH, de Klerk JM, Tan S, van het Schip AD, Derksen BH, et al. (2002) The PLACORHEN study: a double-blind, placebo-controlled, randomized radionuclide study with (186)Re-etidronate in hormoneresistant prostate cancer patients with painful bone metastases. Placebo Controlled Rhenium Study. J Nucl Med 43: 1150-1156.

28. Maxon HR 3rd, Schroder LE, Hertzberg VS, Thomas SR, Englaro EE, et al. (1991) Rhenium-186(Sn)HEDP for treatment of painful osseous metastases: results of a double-blind crossover comparison with placebo. J Nucl Med 32: 1877-1881.

29. Parker C, Heinrich D, O'Sullivan JM, et al. Overall survival benefit and safety profile of radium-223 chloride, a first-in-class alphapharmaceutical: results from a phase III randomized trial (ALSYMPCA) in patients with castration-resistant prostate cancer (CRPC) with bone metastases. J Clin Oncol. 2012;30(supp 5). Abstract 8.

30. Dafermou A, Colamussi P, Giganti M, Cittanti C, Bestagno M, et al. (2001) A multicentre observational study of radionuclide therapy in patients with painful bone metastases of prostate cancer. Eur J Nucl Med 28: 788-798.

31. Zafeirakis A, Papatheodorou G, Arhontakis A, Gouliamos A, Vlahos L, (2010) et al. Predictive implications of bone turnover markers after palliative treatment with (186)Re-HEDP in hormone-refractory prostate cancer patients with painful osseous metastases. Eur J Nucl Med Mol Imaging 37:103-113.

32. O'Sullivan JM, McCready VR, Flux G, Norman AR, Buffa FM, et al. (2002) High activity Rhenium-186 HEDP with autologous peripheral blood stem cell rescue: a phase I study in progressive hormone refractory prostate cancer metastatic to bone. Br J Cancer 86: 1715-1720.

33. O'Sullivan JM, Norman AR, McCready VR, Flux G, Buffa FM, et al. (2006) A phase 2 study of high-activity 186Re-HEDP with autologous peripheral blood stem cell transplant in progressive hormone-refractory prostate cancer metastatic to bone. Eur J Nucl Med Mol Imaging 33: 1055-1061.

34. Fosså SD, Paus E, Lochoff M, Backe SM, Aas M (1992) 89Strontium in bone metastases from hormone resistant prostate cancer: palliation effect and biochemical changes. Br J Cancer 66: 177-180.

35. Parker CC, Pascoe S, Chodacki A, O'Sullivan JM, Germá JR, et al. (2013) A randomized, double-blind, dose-finding, multicenter, phase 2 study of radium chloride $(\mathrm{Ra} 223)$ in patients with bone metastases and castration-resistant prostate cancer. Eur Urol 63: 189-197.

36. Palmedo H, Manka-Waluch A, Albers P, Schmidt-Wolf IG, Reinhardt M et al. (2003) Repeated bone-targeted therapy for hormone-refractory

This article was originally published in a special issue, entitled: "Cancer Radiation Therapy", Edited by University of Arkansas for Medical Sciences USA prostate carcinoma: randomized phase II trial with the new, high-energy radiopharmaceutical rhenium-188 hydroxyethylidenediphosphonate. J Clin Oncol. 21: 2869-2875.

37. Brundage MD, Crook JM, Lukka H (1998) Use of strontium-89 in endocrine-refractory prostate cancer metastatic to bone. Provincial Genitourinary Cancer Disease Site Group. Cancer Prev Control 2: 79-87.

38. https://www.cancercare.on.ca/common/pages/UserFile.aspx? serverId=6\&path=/File\%20Database/CCO\%20Files/PEBC/pebc14-1f.pdf

39. Parker C, Nilsson S, Heinrich D, Helle SI, O'Sullivan JM, et al. (2013) Alpha emitter radium-223 and survival in metastatic prostate cancer. $\mathrm{N}$ Engl J Med 369: 213-223.

40. Englaro EE, Schroder LE, Thomas SR, Williams CC, Maxon HR 3rd (1992) Safety and efficacy of repeated sequential administrations of Re-186(Sn)HEDP as palliative therapy for painful skeletal metastases. Initial case reports of two patients. Clin Nucl Med 17: 41-44.

41. Pandit-Taskar N, Batraki M, Divgi CR (2004) Radiopharmaceutical therapy for palliation of bone pain from osseous metastases. J Nucl Med 45: 1358-1365.

42. Cookson MS, Roth BJ, Dahm P, Engstrom C, Hussain M, et al. (2013) Castration-Resistant Prostate Cancer: AUA Guideline. J Urol. S0022-5347: 04327-04329.

43. Tomblyn M (2012) The role of bone-seeking radionuclides in the palliative treatment of patients with painful osteoblastic skeletal metastases. Cancer Control 19: 137-144.

44. Sciuto R, Festa A, Rea S, Pasqualoni R, Bergomi S, et al. (2002) Effects of low-dose cisplatin on $89 \mathrm{Sr}$ therapy for painful bone metastases from prostate cancer: a randomized clinical trial. J Nucl Med 43: 79-86.

45. van Dodewaard-de Jong JM, de Klerk JM, Bloemendal HJ, van Bezooijen BP, de Haas MJ, et al. (2011) A phase I study of combined docetaxel and repeated high activity $186 \mathrm{Re}-\mathrm{HEDP}$ in castration-resistant prostate cancer (CRPC) metastatic to bone (the TAXIUM trial). Eur J Nucl Med Mol Imaging 38: 1990-1998.

46. Lin J, Sinibaldi VJ, Carducci MA, Denmeade S, Song D, et al. (2011) Phase I trial with a combination of docetaxel and $\hat{\mathrm{A}}^{1} \hat{\mathrm{a}} \mu \hat{\mathrm{A}}^{3} \mathrm{Sm}$-lexidronam in patients with castration-resistant metastatic prostate cancer. Urol Oncol 29: 670-675.

47. Suttmann H, Grgic A, Lehmann J, Zwergel U, Kamradt J, et al. (2008) Combining 153Sm-lexidronam and docetaxel for the treatment of patients with hormone-refractory prostate cancer: first experience. Cancer Biother Radiopharm 23: 609-618.

48. Fizazi K, Beuzeboc P, Lumbroso J, Haddad V, Massard C, et al. (2009) Phase II trial of consolidation docetaxel and samarium-153 in patients with bone metastases from castration-resistant prostate cancer. J Clin Oncol 27: 2429-2435.

49. Henk G van der Poel (2007) Radionuclide Treatment in Metastasized Prostate Cancer. EAU-EBU Update Series 5:113.

50. Morris MJ, Hammers HJ, Sweeney C, Bloma M, Aksnes AK, et al. (2013) A phase I/IIa study of the safety and efficacy of radium-223 chloride (Ra-223) with docetaxel (D) for castration-resistant prostate cancer (CRPC) patients with bone metastases. J Clin Oncol. 30: TPS4694.

51. Storto G, Klain M, Paone G, Liuzzi R, Molino L, et al. (2006) Combined therapy of Sr-89 and zoledronic acid in patients with painful bone metastases. Bone 39: 35-41.

52. Biersack HJ, Palmedo H, Andris A, Rogenhofer S, Knapp FF, et al. (2011) Palliation and survival after repeated (188)Re-HEDP therapy of hormone-refractory bone metastases of prostate cancer: a retrospective analysis. J Nucl Med 52: 1721-1726. 